Колянко О. В., oksana_20121961@ukr.net, ORCID ID: 0000-0002-1141-1513, Researcher ID: F-7785-201,

к.е.н., дои., доцент кафедри менеджменту, Львівський торговельно-економічний університет, м. Львів

\title{
ОСОБЛИВОСТІ МЕХАНІЗМУ УПРАВЛІННЯ ІНВЕСТИЦІЯМИ В УМОВАХ НЕСТАБІЛЬНОГО СЕРЕДОВИЩА
}

\begin{abstract}
Анотація. В умовах перманентної політичної та економічної кризи в Україні, непередбачуваних викликів внутрішнього та зовнішнього середовища актуальним є обгрунтування детермінант управління інвестиціями на регіональному та місиевому рівнях та стимулювання сочіально-економічного розвитку. Україна потребує суттєвих структурних змін, а ие неможливо без формування механізму відтворення цілісної національної економіки. Обтрунтувано рубрикатори ефективності управління інвестиціями та можливі напрями ї̈ підвищення в умовах нестабільного середовища. Досліджено прагматику економічної ситуації України, проаналізовано напрацювання відомих наукових економічних шкіл у питаннях управління інвестиціями на регіональному та місиевому рівнях. Обгрунтовані теоретико-методичні засади очінювання ефективності управління інвестиціями. Оскільки йдеться про перехід до регульованої ринкової економіки, можна передбачити, щзо методологічно і практично постає досить складне питання взаємодії процесу планування інвестицій із ринковим механізмом, якому не притаманний плановий диктат. Тому роль планування має бути докорінно змінена таким чином, щзоб воно не тиснуло і не заважало розвиткові ринкових відносин в інвестиційному комплексі. Запропоновано напрями підвищення результативності використання важелів управління інвестиціями в умовах нестабільного середовища. Зроблено висновок, щчо важелі стабілізачійної політики працюють не тільки в періоди кризи, а й у випадках необхідності закріплення досягнутого рівня розвитку, підтримки загальної економічної рівноваги за повної зайнятості, стійкого зростання економіки, стабільного рівня цін $і$ збалансованого платіжного балансу, запобігання небажаного виходу параметрів економіки за допустимі межі через вплив на сукупний попит чи сукупну продукцію. Зокрема, підвищення результативності управління економічної політики має проводитися в розрізі ичільового, функиіонального та ресурсного підходів.
\end{abstract}

Ключові слова: управління, інвестиції, інновації, конкурентноспроможність, адаптивні важелі, інституційне середовище, механізм.

Kolyanko O.V., oksana_20121961@ukr.net, ORCID ID: 0000-0002-1141-1513,

Researcher ID: F-7785-201,

Ph.D., Associate Professor, Associate Professor of the Department of Management, Lviv University of Trade and Economics, Lviv

\section{FEATURES OF THE INVESTMENT MANAGEMENT MECHANISM IN THE CONDITIONS OF AN UNSTABLE ENVIRONMENT}

\footnotetext{
Abstract. In the conditions of permanent political and economic crisis in Ukraine, unpredictable challenges of internal and external environment, it is important to substantiate the determinants of investment management at the regional and local levels and create incentives for socio-economic development. Ukraine needs significant structural changes, and this is impossible without the development of a mechanism for the reproduction of a coherent national economy. The rubricators of investment management efficiency and possible directions of its increase in the conditions of unstable environment are substantiated. The pragmatics of the economic situation of Ukraine is studied, the works of well-known scientific economic schools in the issues of investment management at the regional and local levels are analyzed. Theoretical and methodical bases of estimation of investment management efficiency are substantiated. Since we are talking about the transition to a regulated market economy, we can assume that methodologically and practically there is a very difficult question of the interaction of the investment planning process with the market mechanism, for which planned dictate is not inherent. Therefore, the role of planning should be radically changed so that it does not press and does not interfere with the development of market relations in the investment complex. The directions of efficiency increase of investments management levers in the conditions of the unstable environment are proposed. It is
} 


\section{Herald of Lviv University of Trade and Economics. Economic Sciences. № 64, 2021}

concluded that the levers of stabilization policy work not only in times of crisis, but also in cases of need to consolidate the achieved level of development, maintain overall economic balance at full employment, sustainable economic growth, stable prices and balance of payments, prevention of undesirable output of economic parameters due to the impact on aggregate demand or aggregate products. In particular, improving the effectiveness of economic policy management should be carried out in terms of target, function and resource approaches.

Key words: management, investments, innovations, competitiveness, adaptive levers, institutional environment, mechanism.

\section{JEL Classification: H00, H79 \\ DOI: https://doi.org/10.36477/2522-1205-2021-64-08}

Постановка проблеми. Аналіз сучасного стану інвестиційного процесу в регіонах України свідчить про його низьку ефективність, орієнтацію на централізовані методи управління, ігнорування соціально-економічних потреб регіонів і населення, значну його монополізацію на стадіях формування, реалізації і функціонування.

Як слушно зауважує І. Й. Малий, необхідно також вирішити проблему не тільки ерозії суспільної довіри до владних інститутів, яка є фундаментальним імперативом ефективності будь-якої економічної політики, а й процесів ерозії суспільних функцій держави [3, с. 82].

Ю. Кіндзерський акцентує увагу на необхідності розробки прагматичної економічної політики. Дії держави щодо економіки тривалий період часу нагадували перманентне гасіння пожеж. Різкий обвал виробництва, пов'язаний із значними прогалинами в промисловій політиці, відсутністю реальних практичних кроків для досягнення задекларованих у програмно-планових документах цілей, вимагає взаємоузгодження обраної моделі та інструментів економічної політики поставленим цілям соціально-економічного розвитку $[4$, с. 4].

Погоджуємося з В. Нанівською [5, с. 21] про те, що економічна політика держави $€$ реактивною, а не проактивною. Реструктуризація економіки переважно відбувається під тиском зовнішніх шоків і в більшості випадків $\epsilon$ результатом управлінських рішень самого бізнесу, без стратегічного супроводу держави, яка мала б підтримувати реформи та спрямовувати зміни.

Тому для України в умовах політичної та економічної кризи, непередбачуваних викликів внутрішнього та зовнішнього середовища актуальним $є$ обгрунтування детермінант управління інвестиціями на регіональному та місцевому рівнях та стимулювання соціально-економічного розвитку. Україна потребує суттєвих структурних змін, а це неможливо без формування механізму відтворення цілісної національної економіки. Для цього потрібна ефективна економічна політика, яка 3 максимальним рівнем селективності підтримуватиме стратегічно важливі економічні реформи, що сприяють модернізації економіки i прискорять темпи розвитку країни.

Аналіз останніх досліджень і публікацій. У багатьох працях вітчизняних науковців (В. М. Геєця, Н. І. Гражевської, Л. В. Шинкарук, О. Є. Кузьмін, Ф. І. Хміль та ін.) доволі часто позиціонуються питання необхідності інституціональної збалансованості, структурних корекцій в управлінні інвестиціями і підвищення результативності їх реалізації. Нестабільність політичного середовища, великий зовнішній борг та фінансові дисбаланси обмежують простір для стабілізаційного маневру уряду, діючі методи управління стають дедалі неефективними. Все це вимагає радикальних змін та вироблення пропо-зицій щодо ефективності економічної політики.

Постановка завдання. Дослідження полягає в обгрунтуванні рубрикаторів ефективності управління інвестиціями та можливих напрямків підвищення в умовах нестабільного середовища.

Виклад основного матеріалу дослідження. Ситуація в Україні $є$ вкрай непростою. Успадкувавши неефективну економіку зі значними структурними перекосами, інституційним середовищем iз ринкових та статичних інститутів, національна економіка стикнулася 3 проблемами подолання корупції, політичного протистояння, недовіри громадянського суспільства до регулятивної спроможності держави. Сьогодні владі необхідно подолати популізм та волюнтаризм $[1,2]$, які нагромаджувалися впродовж майже 30-ти років, посилити прогностичну, соціальну, алокаційну, превентивну, стимулюючу функції у забезпеченні прогресивного розвитку, забезпечити створення такого інституційного середовища, яке би підтримувало постулати конкурентної економіки, активізувало внутрішні можливості для економічного розвитку, опанувати численні зовнішні переваги, адекватно реагуючи на виклики глобального світу.

За останні роки понад дві третини загальних обсягів капітальних вкладень по Україні спрямувалися на виробниче будівництво і лише одна третина - на розвиток соціальної інфраструктури. Із загального обсягу коштів на виробниче будівництво лише 54-56\% використовувалося на технічне переоснащення і реконструкцію. У критичному стані знаходяться об'єкти охорони здоров'я, освіти i культури.

Отже, потрібен новий підхід до формування і здійснення інвестицій із використанням можливостей регіонального самоуправління і регульованих ринкових відносин. При цьому сам перехід до такої економіки потребує докорінної зміни всієї системи управління інвестиційною діяльністю у регіоні (області, великому місті). Тому виникає гостра необхідність у проведенні роботи зі створення такої системи управління інвестиційноструктурною політикою і процесом реалізації проектів, яка сприяла б забезпеченню нормального функціонування цього механізму. 


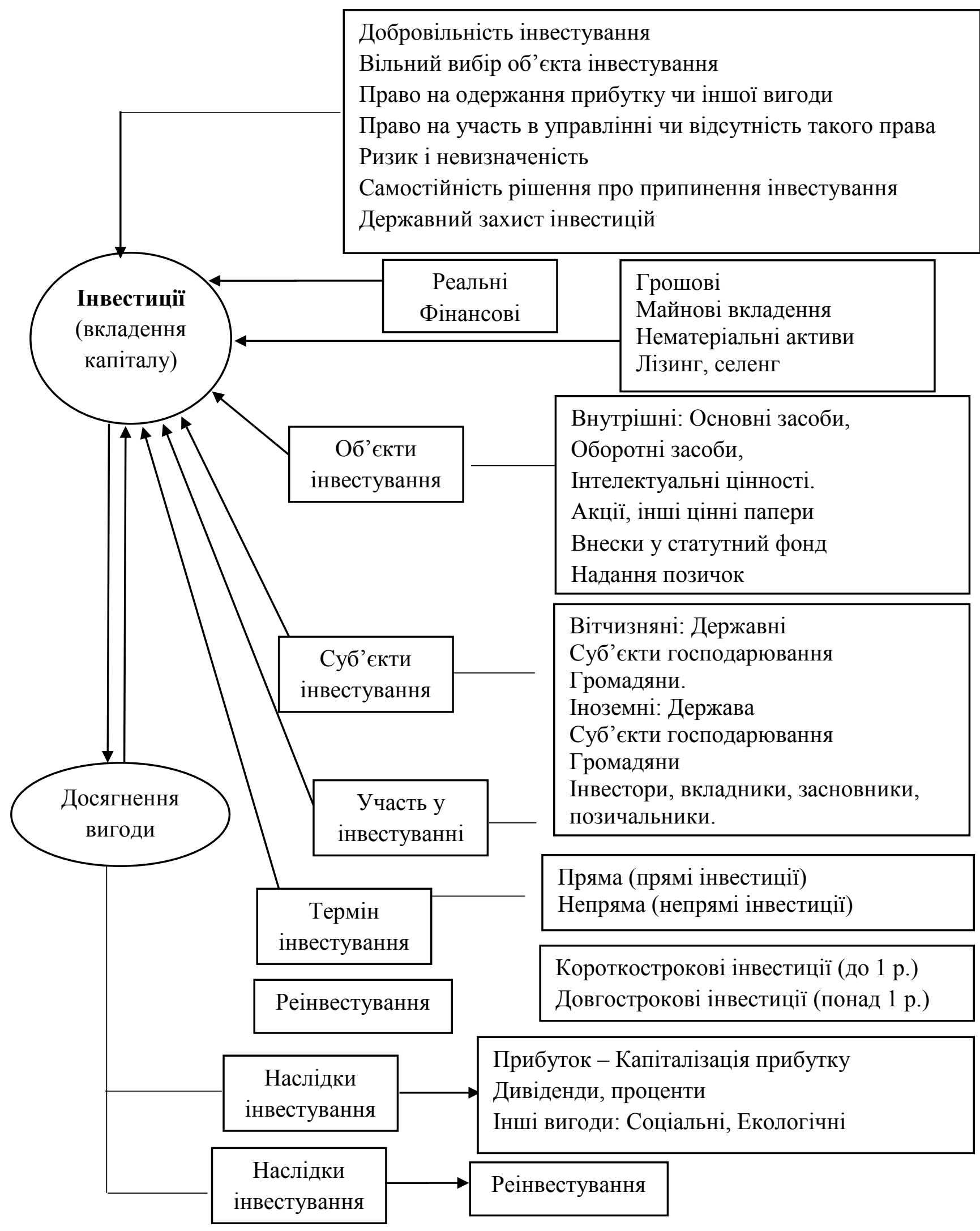

Рис. 1. Структурно-логічна модель інвестування [8]

Інвестиційно-структурна політика формується при створенні загальної концепції розвитку регіону (міста) з метою вирішення соціально-економічних, містобудівних та екологічних завдань. Концепція, яка розробляється відповідно до генерального плану розвитку міста, включає в себе:

- цілі розвитку регіону (міста), конкретизовані до рівня показників економічного і соціального розвитку, включаючи показники життєвого рівня 


\section{Herald of Lviv University of Trade and Economics. Economic Sciences. № 64, 2021}

населення міста, екології і виробничого розвитку міста;

- д джерела формування інвестицій;

- пріоритети розподілу інвестицій;

- заходи, що стимулюють інвестування згідно з визначеними пріоритетами. Інвестиції для розвитку міста виділяються: із місцевого, державного бюджетів, у тому числі для загальнодержавних соціальних програм; за рахунок коштів підприємств (вітчизняних та іноземних) і громади.

Для вирішення питань планування і створення господарського механізму управління інвестиційним процесом доцільно розділити інвестиційний блок і будівельний комплекс регіону на дві групи: перша - це інвестиційний блок і будівельний комплекс, безпосередньо пов'язаний 3 регіоном (областю) за джерелами і об'єктами інвестицій на здійснення власне регіональних інвестиційних проектів (програм), можливістю безпосереднього управління ними з боку місцевих органів влади; друга - це інвестиції, здійснювані (або призначені для здійснення) на території регіону (області), але безпосередньо не пов'язані з регіональними потребами (наприклад, будівництво, реконструкція підприємств загальнодержавного підпорядкування, транспортне будівництво, зв'язок тощо).

Очевидно, що роль і функції місцевих органів влади та іï планово-фінансових органів відносно цих груп інвестицій та елементів будівельного комплексу будуть різними: по першій групі має організовуватись управління з боку регіонального органу влади, а по другій - потрібне державне економічне регулювання діяльності, включаючи засоби для реалізації загальнодержавних інвестиційних програм соціального розвитку.

У галузі планування (як одного з елементів загального протиінфляційного механізму) першочерговим $\epsilon$ чітке розмежування прерогатив і функцій центру (наприклад, Міністерства економіки України, галузевих міністерств і відомств), підприємств і організацій (різноманітних форм власності та структур), місцевих органів влади (обласних рад тощо) залежно від завдань, що вирішуються, та джерел інвестування, включаючи всю систему держзамовлень, які повинні бути переведені переважно на договірну (контрактну) основу.

На нашу думку, слід формувати і муніципальне інвестиційне замовлення, яке встановлюватиметься місцевими органами влади і формуватиметься за рахунок коштів місцевого бюджету та залучених коштів. Склад такого замовлення визначається, виходячи 3 умов раціональної організації інвестиційного процесу із забезпеченням при цьому комплексності будівництва 3 метою створення найбільш сприятливих соціально-побутових умов проживання населення міста.

Об'єктами муніципального інвестиційного замовлення можуть бути як окремі будинки, інженерні споруди, так і містобудівні комплекси, що являють собою сукупність житлових будинків i об’єктів культурно-побутового призначення та інженерного обладнання.
Муніципальне інвестиційне замовлення має формуватися щорічно на основі довгострокових та середньострокових проектів реалізації генерального плану розвитку регіону чи міста.

Планові складові, очевидно, повинні знаходити прояв у розробці інвестиційно-структурної стратегії розвитку регіону, містобудівній і економічній політиці міста, а у перехідний період - й у розробці балансів ресурсів для забезпечення інвестиційної діяльності у регіоні. Має змінитися і сам принцип планування, змістом якого стане не пошук ресурсів під затверджений план, як це було до останнього часу, а навпаки, при цьому планування інвестицій під реальні та можливі для отримання (залучення) обмежується, а за потреби і забороняються. Оцінка об'єктів інвестицій повинна здійснюватися 3 урахуванням їх відповідності містобудівним і економічним вимогам, навантаження на міську інфраструктуру, вкладень у муніципальні соціальні програми, впливу на розвиток експортного потенціалу, насичення ринку товарами та послугами, вирішення проблем зайнятості, надходжень доходів до місцевого бюджету.

Це регулювання необхідно проводити місцевим органам влади на основі єдиної узгодженої політики із застосуванням єдиного методичного підходу до оцінки інвестиційних ініціатив.

Політику координації ініціатив доцільно розробляти на основі аналогу можливостей розвитку регіону і вирішення соціальних проблем за допомогою муніципальних інвестицій із урахуванням прогнозу інвестиційної активності на території. Політика регулювання має відкритий і активний характер, для іiі роз'яснення і залучення нових інвестицій місцевий орган влади використовує рекламні засоби, ділові та наукові контакти, суспільні ініціативи тощо.

Оцінка відповідності політики регулювання завданням розвитку регіону (міста) здійснюється за принципом зворотного зв'язку: муніципальні органи постійно аналізують інформацію про виявлені на території ініціативи, оцінюють ефективність регулюючого втручання i на цій підставі приймають оптимальні рішення.

Оцінка корисності інвестиційних ініціатив базується на критеріях, що дозволяють враховувати вплив передбаченої ініціативи на всі фактори, суттєві з точки зору загальнорегіональних інтересів, як на сьогодні, так і на перспективу. Використання комплексних оцінок забезпечує можливість об'єктивного визначення для кожної з інвестиційних ініціатив характеру регулюючого впливу і його параметрів. За такими суспільно вагомими факторами, як екологія, охорона пам'ятників історії та культури тощо, визначаються порогові значення параметрів, порушення яких спричинює адміністративні санкції. При оцінці умов реалізацій інвестиційних ініціатив враховується також їх вплив на кон'юнктуру попиту i пропозиції будівельних ресурсів та потужностей. Підтримку знаходить залучення додаткових ресурсів і потужностей. 
Контроль здійснюється на всіх етапах інвестиційного процесу. Економічні регулятори, налаштовані на заохочення інвесторів (податкові пільги, знижки тощо), мають умовний характер i передбачають відшкодування інвестором сум отриманих пільг.

У сучасних умовах ефективність економічної політики залежить від іiі спроможності стабілізувати економіку, не допустити руйнівні шоки та нейтралізувати можливі ризики, забезпечити збалансований розвиток. У цій ситуації мають працювати стабілізаційні важелі економічної політики, які можна структурувати на фіскальні, монетарні та комбіновані [6, с. 355]. Застосування цих важелів у світовій практиці знайшло форму шокової терапії та політики сучасного ринку. Варто зауважити, що важелі стабілізаційної політики працюють не тільки в періоди кризи, а й у випадках необхідності закріплення досягнутого рівня розвитку, підтримки загальної економічної рівноваги за повної зайнятості, стійкого зростання економіки, стабільного рівня цін і збалансованого платіжного балансу, запобігання небажаного виходу параметрів економіки за допустимі межі через вплив на сукупний попит чи сукупну продукцію.

Висновки та перспективи подальших досліджень у даному напрямі. Подальше підвищення результативності управління економічної політики має проводитися в розрізі наступних підходів.

По-перше, цільового підходу. Комісія з економічного зростання й розвитку Світового банку, проводячи світ-системний аналіз розвитку країн, вивела національну формулу успіху: 1) максимальне використання переваг відкритої еконо-міки; 2) підтримка параметрів макроекономічної стабільності; 3) довгострокові інвестиції; 4) наявність національного консенсусу 3 приводу цілей розвитку i координації їх досягнення.

По-друге, функціонального підходу. Теорія i практика показують, що економіка розвивається успішно лише тоді, коли держава, здійснюючи економічну політику, створює для цього необхідні умови завдяки реалізації широкого спектра різнорівневих економічних функцій. На нашу думку, пріоритетними для економічної політики у функціональному аспекті мають бути: 1) реалізація стратегічних національних інтересів; 2) включення економіки країни у транснаціональні відтворювальні процеси; 3) сприяння інституційним змінам, спрямованим на підвищення національної конкурентоздатності, стимулювання інноваційно - інвестиційного розвитку, захист національної безпеки.

По-трете, ресурсного підходу. Насамперед необхідно говорити про кадрове забезпечення. Згідно з теорією еліт Парето при владі повинні бути інтелектуальні, економічно грамотні фахівці та прагматичні фінансово спроможні інвестори. Тільки еліта здатна на політичну діяльність, тільки вона може забезпечити справжню свободу, прогрес i стабільність.

\section{ЛIТЕРАТУРА}

1. Лановий В. Уряд розвалив країну / В. Лановий // Економічна правда [Електронний ресурс]. Режим доступу: http:/www.epravda.com.ua/ publikations/2013/12/23/411365/.

2. Савченко О. Економіка після Свромайдану / Савченко О. // Економічна правда [Електронний pecypc]. - Режим доступу: http://iib.com.ua/ novostimib/3560-rektor-mib-oleksandr-savchenkoekonomika-pislya-evromaydanu-pravda/html.

3. Малий I. Й. Ерозія довіри до інститутів держави та конкурентоспроможність національної економіки / І. Й. Малий // Теоретичні та прикладні питання економіки. - 2010. - № 21. - С. 81-88.

4. Кіндзерський Ю. Економічний розвиток i трансформація промислової політики у світі: уроки для України / Ю. Кіндзерський // Економіка України. -2010 . - №5. - С. 4-13.

5. Майбутнє України / За ред. Нанівської В. К. : Центр міжнародних досліджень, 2007. - 54 с.

6. Макроекономіка та макроекономічна політика : навч. посіб. / А. Ф. Мельник, Т. П. Желюк, О. В. Длугопольський, О. В. Панухник. - К. : Знання, 2008. - 699 с.

7. Інноваційний менеджмент: статико-динамічна візуалізація : навч. посіб. / С. В. Князь, Н. Г. Георгіаді, Л. Й. Топоровська, Д. К. Зінкевич. - Львів : Видавництво Львівської політехніки, 2011. - 209 с.

8. Колянко О. В. Регіональне управління інвестиційними процесами : монографія / Колянко О. В. - Львів : Видавництво ЛКА, 2009. - 248 с.

\section{REFERENCES}

1. Lanovyj V. Uriad rozvalyv krainu, Ekonomichna pravda, available at: http://www.epravda.com.ua/ publikations/2013/12/23/411365/.

2. Savchenko O. Ekonomika pislia Yevromajdanu, Ekonomichna pravda, available at: http://iib.com.ua/ novosti-mib/3560-rektor-mib-oleksandr-savchenkoekonomika-pislya-evromaydanu-pravda/html.

3. Malyj, I. J. (2010), Eroziia doviry do instytutiv derzhavy ta konkurentospromozhnist' natsional'noi ekonomiky, Teoretychni ta prykladni pytannia ekonomiky, №21, s. 81-88.

4. Kindzers'kyj Yu. (2010), Ekonomichnyj rozvytok i transformatsiia promyslovoi polityky u sviti: uroky dlia Ukrainy, Ekonomika Ukrainy, №5, s. 4-13.

5. Majbutnie Ukrainy, za red. Nanivs'koi V. (2007), Tsentr mizhnarodnykh doslidzhen', K., 54 s.

6. Mel'nyk, A. F. Zheliuk, T. P. Dluhopol's'kyj, O. V. and Panukhnyk, O. V. (2008), Makroekonomika ta makroekonomichna polityka : navch. posib., Znannia, K., $699 \mathrm{~s}$.

7. Kniaz', S. V. Heorhiadi, N. H. Toporovs'ka, L. J. and Zinkevych, D. K. (2011), Innovatsijnyj menedzhment: statyko-dynamichna vizualizatsiia : navch. posib., Vydavnytstvo L'vivs'koi politekhniky, L'viv, 209 s.

8. Kolianko, O. V. (2009), Rehional'ne upravlinnia investytsijnymy protsesamy : monohrafiia, Vydavnytstvo LKA, L'viv, 248 s.

Стаття надійшла до редакиії 05 серпня 